\title{
The U.S. Geological Survey New England Disciplines Management Council (NEDMAC)
}

\section{Why is sound science important for New England?}

New England, one of the earliest urbanized areas in the United States, encompasses six States, extending from Long Island Sound to the rocky coasts of Maine and to the shores of Lake Champlain. The glaciated terrain, with its diverse geomorphic mix of large sand-and-gravel aquifers, rockbound coasts, sandy beaches, salt marshes, embayments, major rivers, and critical estuary systems, is geographically distinct from the rest of the eastern seaboard. The major watersheds in the region include the Connecticut in Vermont, New Hampshire, Massachusetts, and Connecticut; the Blackstone in Massachusetts and Rhode Island; the Charles in Massachusetts; the Merrimack in Massachusetts and New Hampshire; the Piscataqua in New Hampshire and Maine; the Androscoggin, Kennebec, and Penobscot in Maine; and a part of the St. Lawrence in Maine and Vermont. These watersheds have responded in unique ways to natural and human-induced changes. The New England area is characterized by several unique ecoregions that define much of the native flora and fauna. As urban developmental pressures increase throughout New England, so do the needs for relevant real-time and easy-to-access scientific data. U.S. Geological Survey (USGS) scientists provide a wealth of state-of-the-art research and data to help society understand the complexities of balancing human needs for natural resources and the protection of $\mathrm{New}$ England ecosystems.

\section{What is the New England Disciplines Management Council?}

The New England Disciplines Management Council (NEDMAC) is composed of cost center managers or senior staff representing each of the four USGS science Disciplines (Biological Resources, Geography, Geology, Water Resources) with major programs or offices within the six New England States. Members of NEDMAC include the four Water-Resources Discipline District Chiefs (CT, MA-RI, ME, NH-VT); the Team Chief Scientist and Science Coordinator for the Coastal and Marine Center in Woods Hole, MA; the New England liaison for Eastern Region Geography; the Director of the S.O. Conte Anadromous Fish Research
Laboratory; and the Patuxent Wildlife Research Center's (PWRC) Research Manager for the PWRC Northeastern Field Stations.

\section{NEDMAC's purpose and objectives are to:}

- develop and maintain an awareness of opportunities for collaborative science in the New England area;

- foster communication among the NEDMAC representatives and between NEDMAC and the USGS Eastern Regional Executives;

- coordinate approaches for management of USGS activities in New England;

- promote sharing of resources and responsibilities; and

- identify opportunities to incorporate common business practices and consolidate support functions throughout the New England cost centers when such activity better supports USGS science within New England.

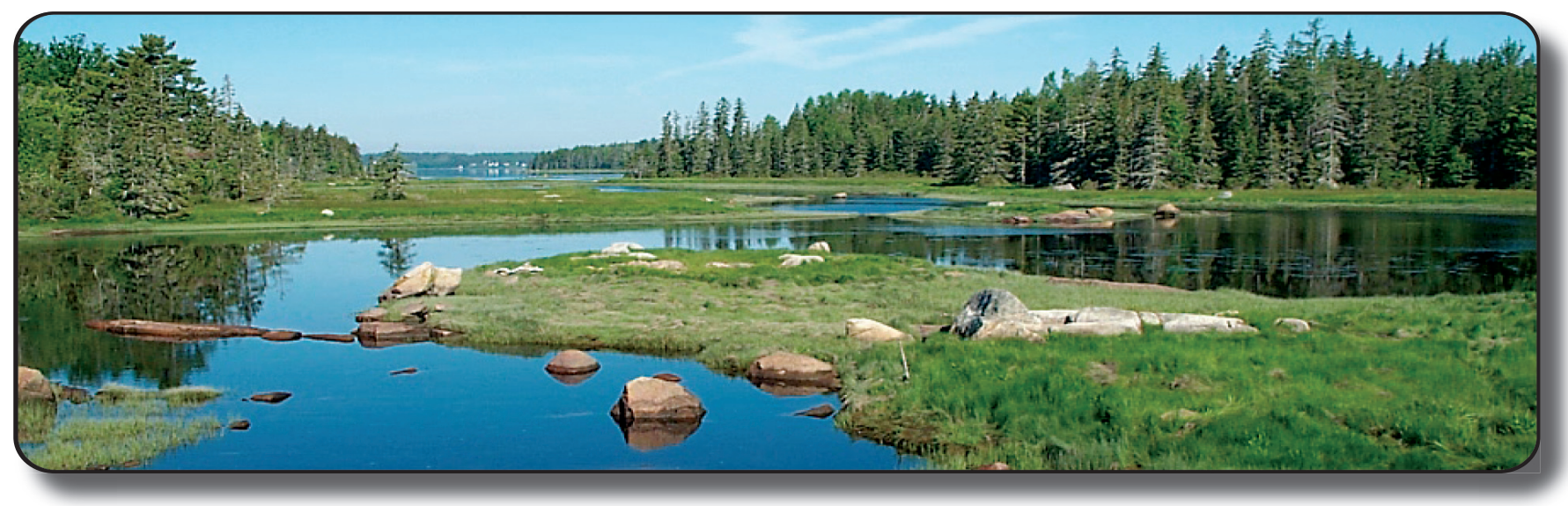

A coastal wetland in New England (Photograph by Hilary A. Neckles, USGS). 


\section{Current Activities}

NEDMAC has focused on science issues related to the impact of human activities on coastal resources in New England. A coastal workshop was held in January 2003 to discuss these issues, and was attended by internal and external stakeholders. This workshop resulted in the publication of a report, Coastal Ecosystems and Resources Framework for Science, which is available online at http://pubs.usgs.gov/of2003/of03405/. NEDMAC will use this framework to guide future USGS efforts to most effectively provide the science necessary to address pressing societal and environmental needs in the New England coastal region.

NEDMAC also is leading a USGS pilot project on water availability for ecosystems and for human use in the Connecticut River watershed. The pilot project is a collaborative effort with the U.S. Fish and Wildlife Service (Region 5) and the University of Massachusetts at Amherst.

\section{Future Efforts}

Future efforts will likely focus on the Connecticut River watershed, Charles River and Boston Harbor, Pleasant Bay, Cape Cod, Penobscot River and Bay, Merrimack River, offshore wind energy, and international boundary areas such as the St. Croix River and its watershed.

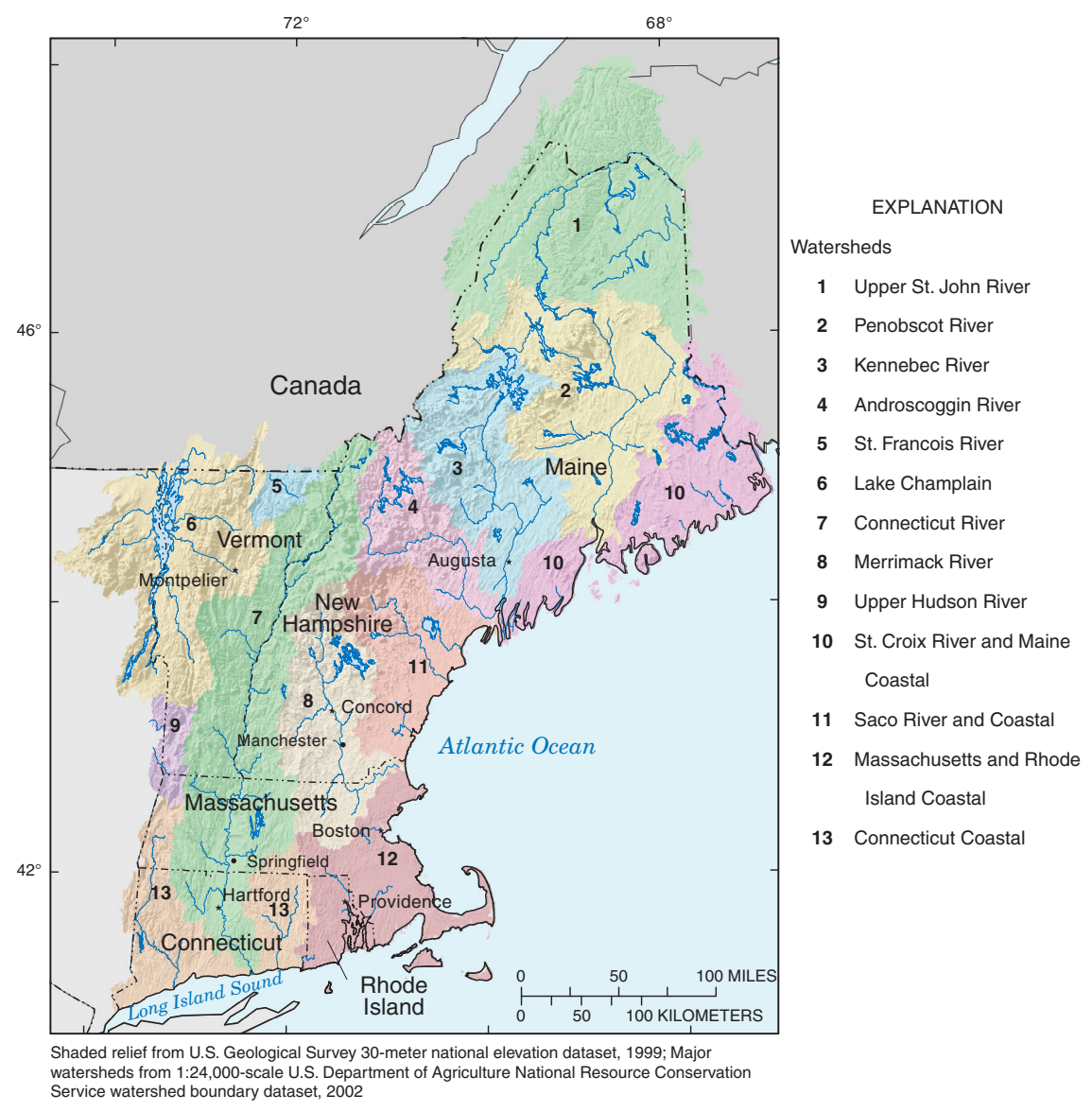

Map showing major watersheds in New England.

NEDMAC intends to host, perhaps on a biennial basis, a New England Science Forum to increase interdisciplinary knowledge of USGS capabilities and ongoing projects. Participants will develop a better understanding of

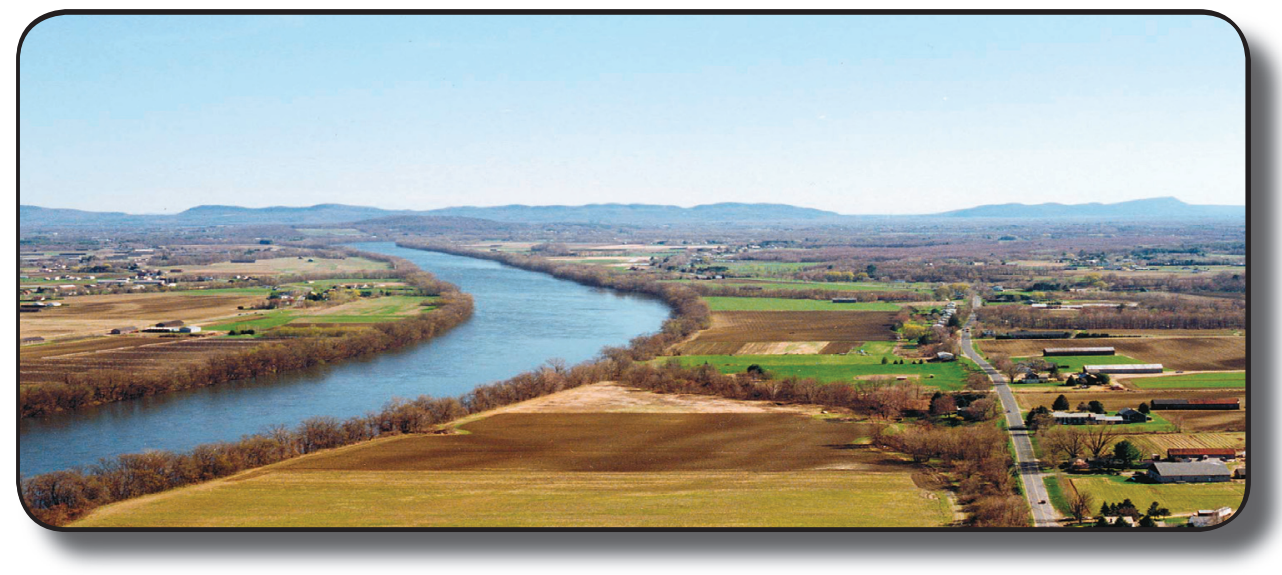

regional science issues and priority needs of a diverse group of clients and stakeholders.

\section{For more information, contact:}

Ellen Mecray

E-mail: emecray@usgs.gov

Phone: (508) 457-2213
Susan Russell-Robinson
E-mail: srussell@usgs.gov
Phone: (703) 648-6682

A view of the Connecticut River flowing through Massachusetts (Photograph by Peter A. Steeves, USGS). 